\title{
ĐÁNH GIÁ THỰC TRẠNG VÀ DỰ TÍNH KHẢ NĂNG XÂM NHẬP MẬN CHO KHU VỰC VEN BIỂN TİNH THÁI BÌNH
}

\author{
Đỗ Đức Thắng ${ }^{1}$, Trần Hồng Thái ${ }^{2}$, Võ Văn Hòa ${ }^{1}$
}

Tóm tắt: Bài báo này trình bày kết quả đánh giá hiện trạng xâm nhập mặn cho khu vực ven biển tỉnh Thái Bình dựa trên bộ số liệu quan trắc độ mặn tù̀ 2000 đến 2017. Kết quả đánh giá cho thấy xâm nhập mặn có thể xâm nhập sâu vào trong nội đồng tù $20-25 \mathrm{~km}$, độ mặn cao nhất đo được tại các trạm vùng cửa sông dao động tù 21 - 27\%o, độ mặn cao nhất đo được tại trạm Ba Lạt (sông Hồng) lên tới 31,8\%o; các năm tù̀ 2003 - 2012 là giai đoạn có độ mặn lón và xâm nhập sâu vào trong đất liền, trong giai đoạn này độ mặn cao nhất đo được tại điểm đo Duong Liễu trên sông Hồng (cách biển $25 \mathrm{~km}$ ) lên tới 16,8\%o. Quá trình mô phỏng và dư báo xâm nhập mặn dựa trên các đương ranh giới xâm nhập mặn 1\%o và 4\%o tại tỉnh Thái Bình đã cho thấy trong tuơng lai duói ảnh hwởng của biến đổi khi hậu, tình trạng xâm nhập mặn trên địa bàn các huyện ven biển ngày càng trở nên nghiêm trọg.

Từ khóa: Xâm nhập mặn, vùng ven biển, Tỉnh Thái Bình.

Ban Biên tập nhận bài: 12/01/2019 Ngày phản biện xong: 05/03/2019 Ngày đăng bài: 25/03/2019

\section{Mở đầu}

Với 157 nghìn ha đất tự nhiên trong đó có 97,2 nghìn ha sử dụng cho phát triển nông nghiệp, Thái Bình được đánh giá là một trong 4 tỉnh ven biển đồng bằng sông Hồng có tiềm năng phát triển nông nghiệp. Hiện tại, diện tích đất sử dụng trong nông nghiệp của tỉnh chủ yếu là trồng lúa. Việc phát triển nông nghiệp nói chung và trồng lúa nói riêng tại đây phụ thuộc lớn vào hệ thống sông Hồng - Thái Bình. Hệ thống sông này là nguồn cung cấp nước chính thông qua việc phân vào các cống lấy nước và trạm bơm. Tuy nhiên, chịu ảnh hưởng của dòng chảy kiệt, nước biển dâng làm cho ranh giới xâm nhập mặn tiến sâu vào trong sông. Mặc dù nước mặn không xâm nhập vào trong nội đồng do có hệ thống đê khống chế vùng cửa sông nhưng chính việc xâm nhập mặn đã khiến quá trình lấy nước tưới từ sông phục vụ nông nghiệp, nuôi trồng thủy sản bị ảnh hưởng. Điều này dẫn đến 10-20\% diện tích nông nghiệp vụ Đông Xuân khó khăn về nguồn nước tưới. Chi phí cho nông nghiệp cũng khá tốn kém song sản lượng, chất lượng lúa giảm
6-10\% so với những năm đủ nước tưới. Việc thiếu nước tưới được xác định do hai nguyên nhân chính là thực trạng hạn hán trong những năm gần đây do trên hệ thống sông Hồng - Thái Bình dòng chảy mùa kiệt bị ảnh hưởng mạnh của việc khai thác các công trình lấy nước. Bên cạnh đó là thực trạng xâm nhập mặn diễn ra ngày càng mạnh và phức tạp do lưu lượng về hạ lưu giảm, mực nước sông xuống thấp và nước biển dâng cao kết hợp triều cường. Nhiều nghiên cứu đã chỉ ra rằng vào mùa kiệt, nước phục vụ cho sản xuất nông nghiệp và thủy sản ở Thái Bình có độ mặn vượt quá nồng độ cho phép đã làm giảm năng suất cây trồng [1-4].

Tác động của biến đổi khí hậu (BĐKH) đã dẫn đến tình trạng nước biển xâm nhập sâu vào vùng đất liền làm cho diện tích canh tác tại các địa phương của tỉnh Thái Bình bị nhiễm mặn. Theo đánh giá của Sở Tài nguyên và Môi trường tỉnh Thái Bình [5], nếu mực nước biển dâng 50 $\mathrm{cm}$ thì diện tích đất có nguy cơ ngập trên địa bàn tỉnh là $11,8 \%$; nếu dâng lên $100 \mathrm{~cm}$ thì sẽ có khoảng 31,4\% diện tích có nguy cơ bị ngập... Dự

${ }^{1}$ Đài Khí tương Thủy văn khu vực đồng bằng Bắc Bộ

${ }^{2}$ Tổng cuc Khi tượng Thủy văn

Email: thangtv1967@gmail.com 


\section{BÀI BÁO KHOA HỌC}

báo đến năm 2100, tỉnh Thái Bình sẽ bị xâm nhập mặn sâu thêm vào đất liền từ $3-9 \mathrm{~km}$, uy hiếp trực tiếp đến an toàn hệ thống hồ chứa và hệ thống đê. Sự diễn biến phức tạp của khí hậu, sự thay đổi các dòng chảy của sông, mực nước biển dâng đã và đang gây ra các hiện tượng sạt lở, xói mòn các bờ sông, bờ biển, phá hủy nhiều công trình hạ tầng sơ sở. Hiện tượng sạt lở diễn ra ở hầu hết các con sông chính chảy qua địa bàn tỉnh như sông Hồng, sông Trà Lý, sông Luộc... Điều này ảnh hưởng nghiêm trọng đến đời sống sản xuất, sinh hoạt của người dân. Với đường bờ biển dài $23 \mathrm{~km}$, có 2 cửa sông lớn đổ ra biển, nguy cơ nhiễm mặn luôn hiện hữu. Hiện tượng nước biển dâng, xâm nhập mặn tiến sâu vào nội địa gây nhiễm mặn nguồn nước, ảnh hưởng lớn đến nguồn nước tưới gây thiệt hại lớn cho sản xuất nông nghiệp và đời sống của nhân dân. Tác động của BĐKH đã làm thay đổi một số quy luật tự nhiên, môi trường, tác động tiêu cực đến hệ sinh thái rừng vùng ven biển. Do đó, việc nghiên cứu đánh giá và chỉ ra được thực trạng xâm nhập mặn cũng như dự tính khả năng xâm nhập mặn trong tương lai cho khu vực ven biển Thái Bình là hết sức cần thiết.

\section{Mô tả tập số liệu và phương pháp nghiên cứu}

Để có được số liệu cụ thể và đầy đủ phục vụ cho việc nghiên cứu, các tác giả đã sử dụng những nguồn số liệu sau: Số liệu tại các Trạm khí tượng, thủy văn thuộc tỉnh Thái Bình; Số liệu thu thập từ quá trình đi điều tra khảo sát; Số liệu từ niên giám thống kê tại tỉnh Thái Bình và các nguồn số liệu từ các đề tài, dự án, báo cáo, chương trình khoa học có các số liệu liên quan tại tỉnh Thái Bình.

Trong nghiên cứu này, số liệu khí tượng thủy văn được sử dụng bao gồm số liệu quan trắc tại: Trạm khí tượng đặt tại xã Vũ Ninh, huyện Kiến Xương; 6 trạm thủy văn trong đó có 3 trạm hạng I là Trạm thủy văn Triều Dương, Quyết Chiến, Ba Lạt; 03 trạm hạng III là Trạm thủy văn Tiến Đức (Nhật Tảo), thành phố Thái Bình, Đông Quí; 6 điểm đo mặn là Vân Cù, Ngũ Thôn, Phúc Khê, Đông Quí, Ba Lạt, Dương Liễu. Trong nghiên cứu này, tác giả chỉ sử dụng số liệu tại các trạm tại tỉnh Thái Bình đã được công bố bởi Bộ Tài nguyên và Môi trường (2016) trong bản "Kịch bản biến đổi khí hậu, nước biển dâng cho Việt Nam". Vị trí của các trạm quan trắc, các điểm đo mặn và các điểm đo mưa tự động được trình bày trong hình 1 .

- Số liệu quan trắc lượng mưa, nhiệt độ ngày cập nhật đến năm 2017;

- Số liệu quan trắc mặn tại 6 điểm đo mặn đến năm 2017;

- Số liệu dự tính lượng mưa, nhiệt độ theo kịch bản RCP4.5 và RCP8.5 đã qua hiệu chỉnh thống kê bằng phương pháp hiệu chỉnh phân vị.

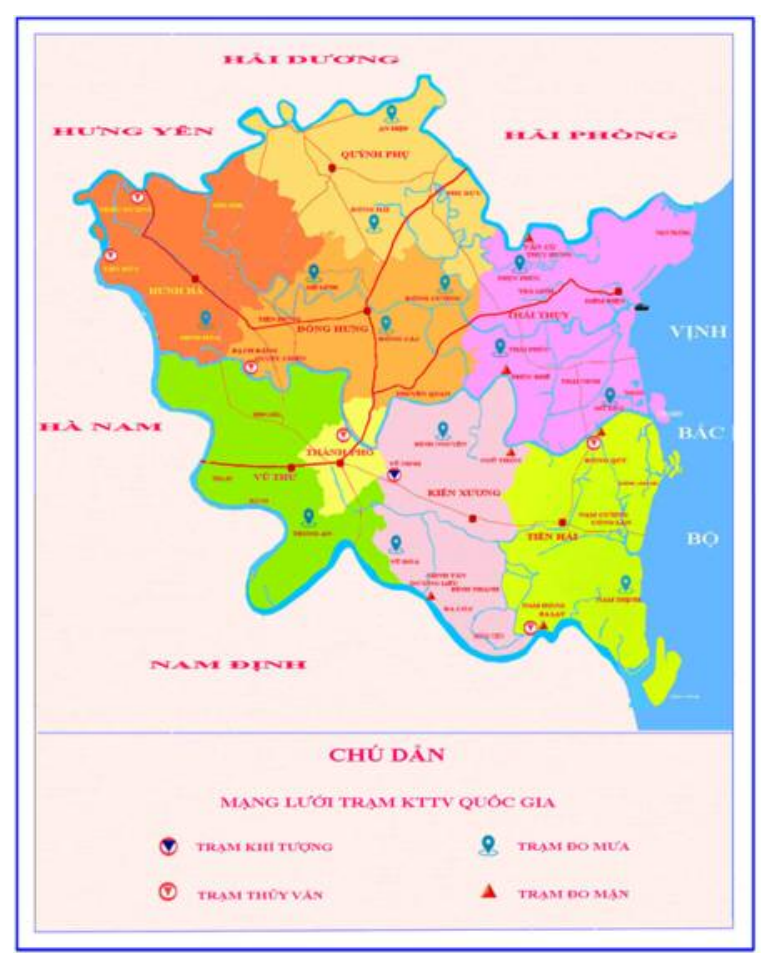

Hình 1. Bản đồ mạng lưới Trạm khi tượng thủy văn tỉnh Thái Bình

Do nước tưới nông nghiệp tại tỉnh Thái Bình được lấy chủ yếu từ hệ thống sông Hồng - Thái Bình nên độ mặn tại một số sông nhánh của hệ thống sông Hồng - Thái Bình như: sông Trà Lý, sông Kiến Giang, sông Lân, sông Luộc và một số sông khác có thể coi là độ mặn nước tưới trồng lúa của tỉnh Thái Bình. Vì vậy, bài toán dự báo tác động của biến đổi khí hậu đến xâm nhập mặn tại tỉnh Thái Bình sẽ thành bài toán dự báo xâm nhập mặn hệ thống sông Hồng - Thái Bình 
tới năm 2100. Do đó, cần phải giải quyết bài toán thủy lực và lan truyền chất. Hay nói cách khác là cần nghiên cứu cách áp dụng mô hình 1 chiều giải hệ phương trình Saint - Venant (gồm phương trình liên tục và chuyển động, nghiệm là mực nước và lưu lượng/vận tốc) và mô hình lan truyền chất với hệ phương trình truyền tải khuếch tán. Những mô hình kiểu này cho phép tính toán mô phỏng quá trình thuỷ động lực và khuếch tán trong toàn bộ mạng lưới sông. Trong nghiên cứu này, chúng tôi sử dụng mô hình Mike 11 của Viện Thuỷ lực DHI, Đan Mạch là một trong các mô hình 1 chiều tiên tiến thế giới hiện nay, được sử dụng rộng rãi trong các trường đại học, viện nghiên cứu và các đơn vị tư vấn ở trong và ngoài nước [6].

3. Kết quả đánh giá hiện trạng và dự tính xâm nhập mặn cho khu vực ven biển tỉnh

\section{Thái Bình}

\subsection{Kết quả đánh giá thực trạngxâm nhập mặn}

Thái Bình là một tỉnh có nhiều cửa sông lớn đổ ra biển, mặn có thể xâm nhập sâu vào trong nội đồng từ 20 - 25 km (Hình 2), độ mặn cao nhất đo được tại các trạm vùng cửa sông dao động từ 21 27\%o, độ mặn cao nhất đo được tại Trạm thủy văn Ba Lạt (sông Hồng) lên tới 31,8\%; trong các năm từ năm 2003 - 2012 là giai đoạn có độ mặn lớn và xâm nhập sâu vào trong đất liền, trong giai đoạn này độ mặn cao nhất đo được tại trạm Dương Liễu trên sông Hồng (cách biển $25 \mathrm{~km}$ ) lên tới 16,8\%; trong những năm gần đây độ mặn không có xu hướng tăng cao chủ yếu là do các nhà máy thủy điện tăng cường xả nước đổ ải vụ Đông Xuân làm cho độ mặn cũng giảm đi. Hình 2 đến hình 5 thể hiện xu thế biến đổi độ mặn của các trạm trên địa bàn tỉnh Thái Bình trong nhiều năm.

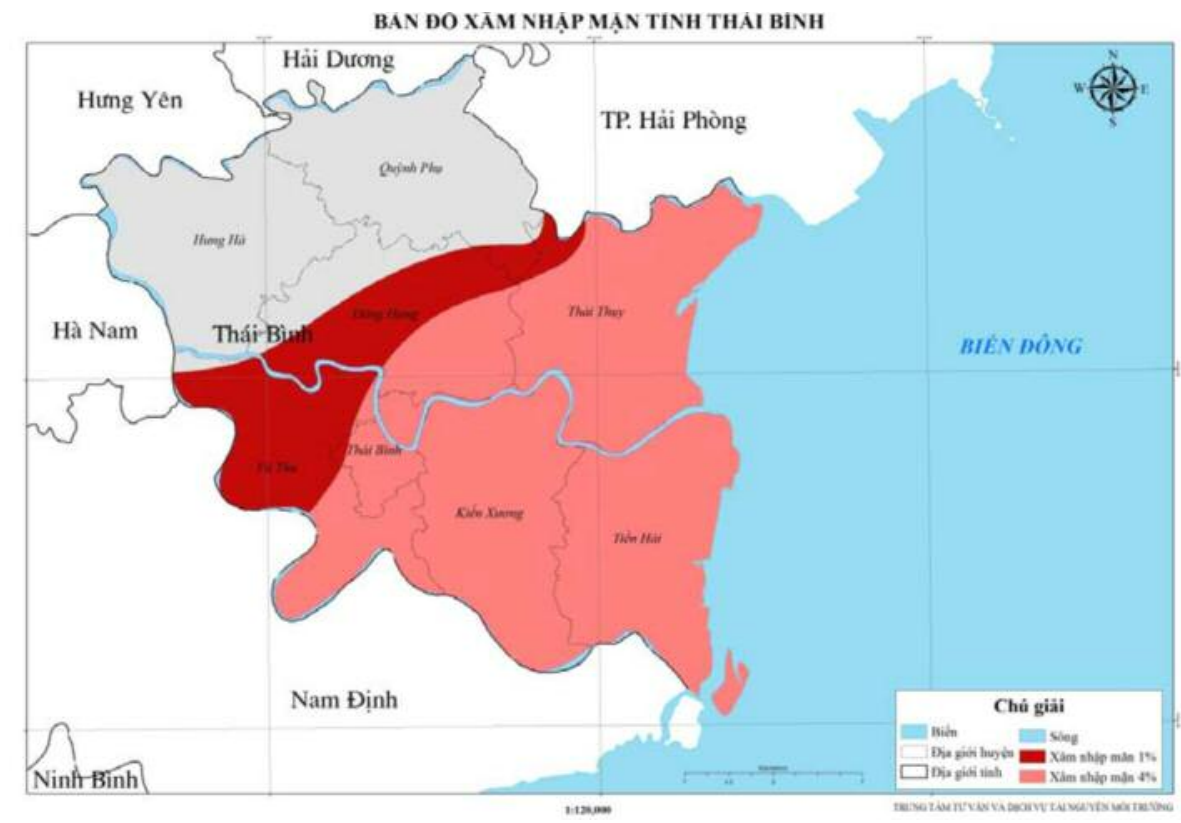

Hình 2. Xâm nhập mặn lớn nhất tại tỉnh Thái Bình

Kết quả tính toán cho thấy xu thế chân mặn lớn nhất tại đa số các trạm trên sông Hồng, sông Trà lý, sông Hóa có chiều hướng giảm (hình $3 \mathrm{a}$, 3b). Riêng trạm Đông Quý xu thế độ mặn không có nhiều thay đổi qua các năm. Độ mặn trên các sông thuộc tỉnh Thái Bình phụ thuộc vào sự điều tiết của các hồ chứa Hòa Bình, Thác Bà và Tuyên Quang. Nhìn chung tổng lượng nước trên hệ thống sông là khá lớn tuy nhiên có sự phân bố không đồng đều theo thời gian và không gian. Trong 7 - 9 tháng mùa khô, tổng lượng dòng chảy chỉ chiếm 20 - 30\% tổng lượng dòng chảy năm. Những năm trước đây cùng với hoạt động ngăn dòng của các hồ chứa phục vụ cho phát triển thủy điện dẫn đến nguồn nước bổ xung từ thượng nguồn không đủ để đẩy mặn và hiện tượng hạn hán, nước biển dâng khiến cho tình trạng xâm nhập mặn tại khu vực ngày càng trở 
nên khắc nghiệt. Theo số liệu thống kê chân mặn lớn nhất trong giai đoạn từ 2000 - 2010 tại Trạm thủy văn Ba Lạt giao động trong khoảng từ 3 8,25\%, Đông Quý là 0,2 - 2,48\%, Dương Liễu là $0,5-0,7 \%$, tại Ngũ Thôn 0,2 - 3\%o. Hai điểm đo Phúc Khê và Vân Cù giao động trong khoảng $0,04-0,35 \%$. Tuy nhiên trong những năm gần đây xu thế chân mặn giảm dần do các hoạt động điều tiết tại các hồ chứa đặc biệt trong các thời điểm mùa khô nhằm cung cấp nguồn nước tưới cho vùng hạ du và làm giảm đi tác tác động của xâm nhập mặn tại khu vực.

Đối với xu thế đỉnh mặn, các kết quả tính toán cho thấy xu thế đỉnh mặn lớn nhất của các trạm trên sông Hồng, sông Trà Lý, sông Hóa cho thấy tại hầu hết các trạm độ mặn có xu hướng giảm theo các năm (hình $3 \mathrm{c}, 3 \mathrm{~d}$ ). Riêng điểm đo Ngũ Thôn độ mặn có xu thế tăng tuy nhiên mức tăng không đáng kể. Những năm gần đây mặc dù xu thế đỉnh mặn lớn nhất có giảm đi so với các năm trước đây do những nỗ lực khắc phục của các cấp chính quyền bằng cách có kế hoạch vận hành các hồ chứa phù hợp, điều tiết nước nhằm cung cấp nước tưới, chống hạn cho mùa khô. Tuy nhiên hiện trạng thực tế cho thấy, nước mặn vẫn ngày càng lấn sâu hơn vào khu vực hai huyện Thái Thụy, Tiền Hải do tình trạng hạn hán diễn ra thường xuyên hơn cùng với hiện tượng nước biển dâng ngày càng diễn biến phức tạp. Những năm qua vụ Xuân bị ảnh hưởng của mặn trên triền sông Hoá lên tới khu vực cầu Nghìn, triền Trà lý mặn ảnh hưởng lên qua cống Thái Phúc tới giáp cống Thuyền Quan là cống lấy nguồn nước chủ yếu của vùng Nam huyện Thái Thụy, triền sông Hồng mặn xâm nhập lên tới cống Nguyệt Lâm là cống lấy nguồn nước chủ yếu của huyện Tiền Hải. Những ảnh hưởng của xâm nhập mặn gây rất nhiều khó khăn cho việc canh tác lúa của người dân.

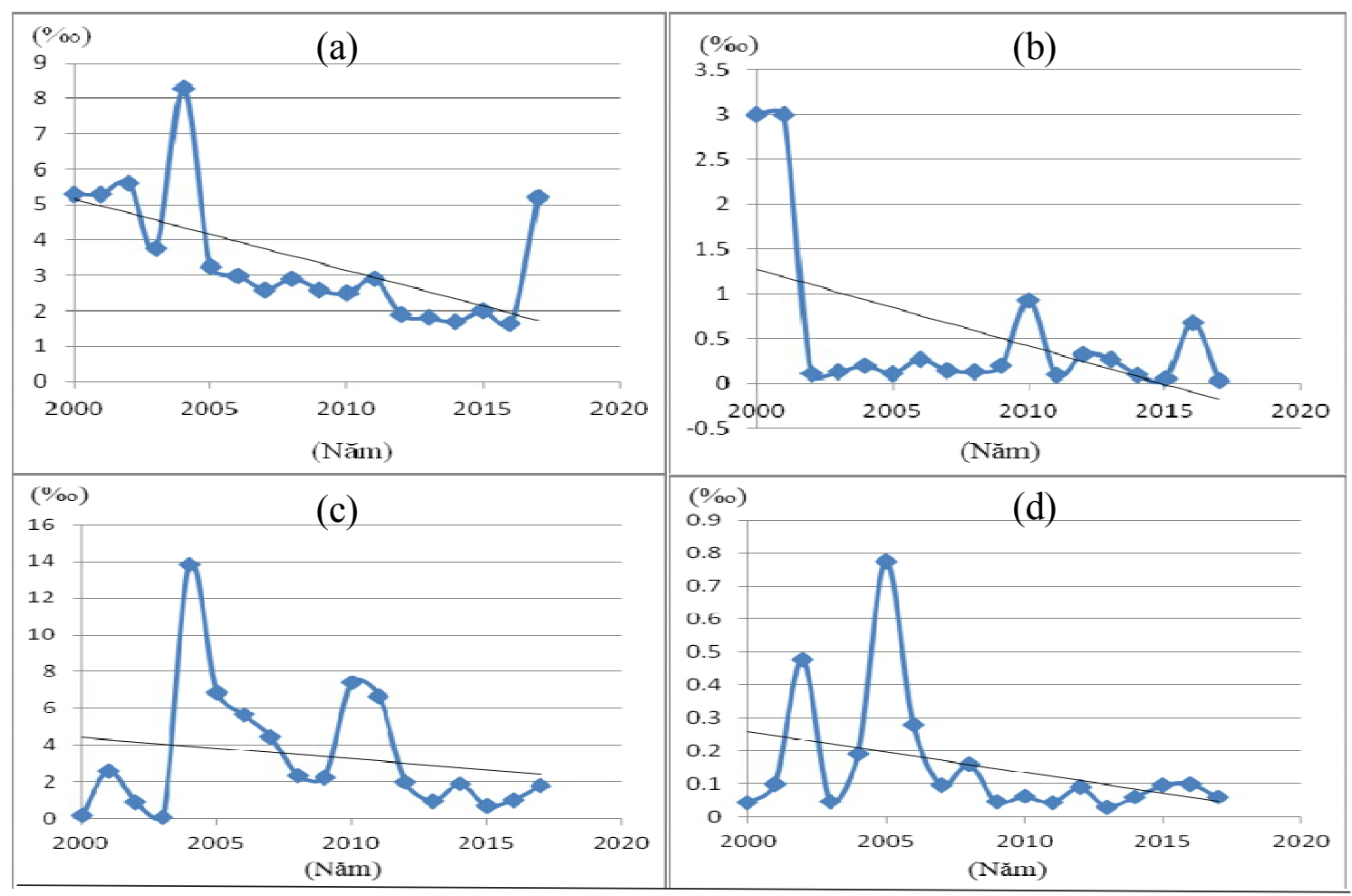

Hình 3. (a) Xu thế chân mặn lớn nhất Trạm thủy văn Ba Lạt; (b) Xu thế chân mặn lớn nhất điểm đo Ngũ Thôn; (c) Xu thế đỉnh mặn lớn nhất điểm đo Phúc Khê; (d) Xu thế đỉnh mặn lớn nhất điểm đo Vân Cù 


\subsection{Kết quả dụ tính xâm nhập mặn}

Dựa trên kịch bản nồng độ khí nhà kính trung bình thấp (RCP4.5), nhóm nghiên cứu đã tiến hành chạy mô hình Mike 11 để tính toán mức độ xâm nhập mặn theo kịch bản RCP 4.5 trên hệ thống sông Hồng - Thái Bình. Các hình 4 và hình 5 , các bảng 1 , bảng 2 lần lượt đưa ra các kết quả tính toán mô phỏng ranh giới xâm nhập mặn và bảng đánh giá mức độ xâm nhập mặn tương ứng. Các kết quả tính toán cho thấy:

+ Trong khoảng giai đoạn từ hiện trạng đến 2030, mực nước biển dâng lên khoảng $17 \mathrm{~cm}$ thì mức độ xâm nhập mặn diễn biến tương đối ổn định và mức tăng là không lớn. Với ranh giới mặn 1\%o mức tăng trung bình là $1,09 \mathrm{~km}$ mức tăng lớn nhất là $1,6 \mathrm{~km}$ trên sông Trà Lý, mức tăng thấp nhất là $0,2 \mathrm{~km}$ trên sông Thái Bình. Tuy nhiên, đến giai đoạn 2050 với mực nước biển dâng lên khoảng $28 \mathrm{~cm}$ thì tương quan mức độ tăng xâm nhập mặn giữa các sông đã có sự thay đổi lớn không chỉ về xu hướng mà cả về lượng. Vẫn là ranh giới mặn 1\%o nhưng mức tăng lớn nhất là $4 \mathrm{~km}$ diễn ra trên sông Thái Bình, mức tăng thấp nhất là $1,7 \mathrm{~km}$ diễn ra trên sông Trà Lý. Trong giai đoạn từ 2050 đến 2099 khi mà nước biển dâng lên thêm $65 \mathrm{~cm}$ thì mức tăng xâm nhập mặn lớn nhất là 8,1 km tại sông Thái Bình, thấp nhất là 2,4km tại sông Trà Lý.

+ So với ranh giới mặn 1\%o, ranh giới mặn 4\%o có mức độ xâm nhập và thay đổi nhỏ hơn. Trong giai đoạn hiện trạng đến 2030 khi mực nước biển dâng lên khoảng $17 \mathrm{~cm}$ thì mức tăng xâm nhập mặn lớn nhất là 1,4km tại sông Trà Lý và thấp nhất là 0,1 tại sông Hồng. Đến giai đoạn sau từ 2030 - 2050 khi mực nước biển dâng lên khoảng $28 \mathrm{~cm}$ thì mức tăng bình quân lớn nhất là $1,7 \mathrm{~km}$ trên sông Trà Lý và thấp nhất trên sông Thái Bình với $1,3 \mathrm{~km}$. Nhưng trong 50 năm của giai đoạn 2050 - 2099 thì mức tăng lớn nhất là $3,9 \mathrm{~km}$ trên sông Thái Bình và nhỏ nhất là 2,1 km trên sông Trà Lý.

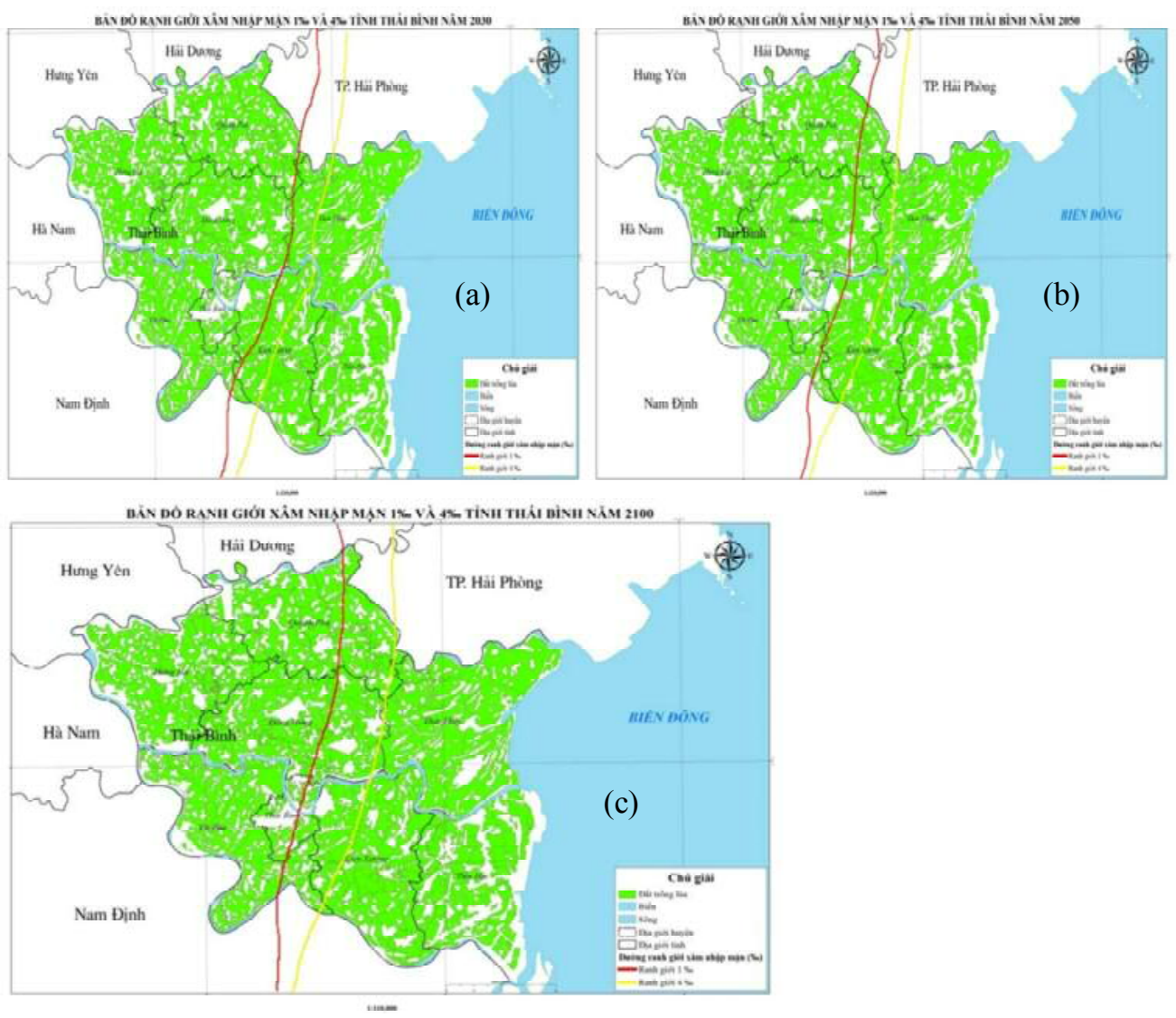

Hình 4. Mô phỏng ranh giới xâm nhập mặn 1\%o và 4\%o theo kịch bản RCP 4.5 cho các năm 2030 (a), 2050 (b) và 2100 (c) cho tỉnh Thái Bình 


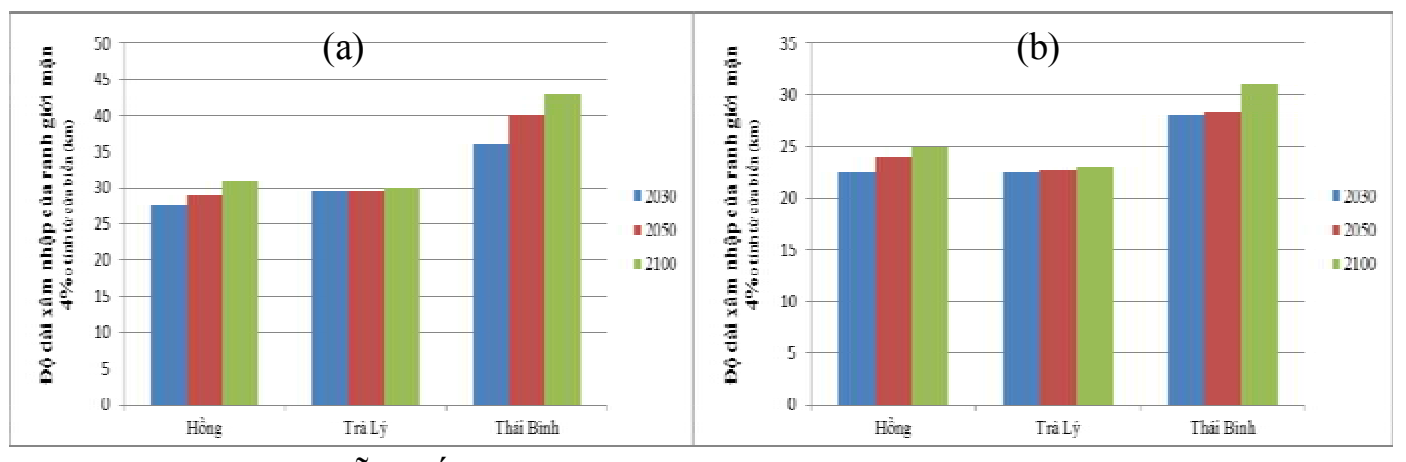

Hình 5. Mô phỏng diễn biến ranh giới xâm nhập mặn 1\%o (a) và 4\%o (b) dọc trên các sông theo kịch bản RCP 4.5 cho các năm 2030, 2050, 2099

Bảng 1. Đánh giá mức độ xâm nhập mặn tại một số cưa sông theo kịch bản RCP $4.5(\mathrm{~km})$

\begin{tabular}{lcccccc}
\hline \multicolumn{2}{c}{ Kịch bản RCP 4.5 } & \multicolumn{3}{c}{$1 \%$ o } & \multicolumn{3}{c}{$4 \% 0$} \\
\hline \multicolumn{1}{c}{ Sông } & 2030 & 2050 & 2099 & 2030 & 2050 & 2099 \\
\hline Hồng & 27,4 & 29,3 & 31,1 & 22,1 & 23,5 & 24,9 \\
Trà Lý & 28,9 & 29,0 & 29,7 & 22,4 & 22,7 & 23,1 \\
Thái Bình & 36,2 & 40 & 44,1 & 28,3 & 28,8 & 31,4 \\
\hline
\end{tabular}

Bảng 2. So sánh mức tăng xâm nhập mặn giữa kịch bản RCP 4.5 và hiện trạng $(\mathrm{km})$

\begin{tabular}{lcccccc}
\hline \multicolumn{2}{c}{ Kịch bản RCP 4.5 } & \multicolumn{2}{c}{2030} & \multicolumn{2}{c}{2050} & \multicolumn{2}{c}{2099} \\
\hline \multicolumn{1}{c}{ Sông } & $1 \% 0$ & $4 \% 0$ & $1 \% 0$ & $4 \% 0$ & $1 \% 0$ & $4 \% 0$ \\
\hline Hồng & 0,6 & 0,1 & 2,5 & 1,5 & 4,3 & 2,9 \\
Trà Lý & 1,6 & 1,4 & 1,7 & 1,7 & 2,4 & 2,1 \\
Thái Bình & 0,2 & 0,8 & 4,0 & 1,3 & 8,1 & 3,9 \\
\hline
\end{tabular}

Bảng 3. Diện tích trồng lúa có nguy co bị ảnh hưởng bởi xâm nhập mặn tỉnh Thái Bình

(Đơn vị: Nghin ha)

\begin{tabular}{|c|c|c|c|c|c|c|c|}
\hline \multirow[t]{2}{*}{ Huyện/Thành Phố } & \multirow[t]{2}{*}{$\begin{array}{l}\text { Diện tích } \\
\text { trồng lúa }\end{array}$} & \multicolumn{3}{|c|}{$\begin{array}{l}\text { Diện tích trồng lúa có } \\
\text { nguy cơ ảnh hường bởi } \\
\text { xâm nhập mặn } 1 \% \mathrm{o}\end{array}$} & \multicolumn{3}{|c|}{$\begin{array}{l}\text { Diện tích trồng lúa có } \\
\text { nguy cơ ảnh hưởng bởi } \\
\text { xâm nhập mặn } 4 \% \mathrm{o}\end{array}$} \\
\hline & & 2030 & 2050 & 2099 & 2030 & 2050 & 2099 \\
\hline Thành phố Thái Bình & 4,8 & 0 & 0 & 1,2 & 0 & 0 & 0 \\
\hline Huyện Quỳnh Phụ & 23,1 & 0,23 & 3,85 & 6,93 & 0 & 0 & 1,85 \\
\hline Huyện Hưng Hà & 21,8 & 0 & 0 & 0 & 0 & 0 & 0 \\
\hline Huyện Đông Hưng & 23,2 & 0,06 & 4,64 & 6,96 & 0 & 0 & 0,35 \\
\hline Huyện Thái Thụy & 26,5 & 21,2 & 22,7 & 22,7 & 20,3 & 21,32 & 22,1 \\
\hline Huyện Tiền Hải & 20,6 & 13,4 & 13,4 & 13,4 & 13,4 & 13,4 & 13,4 \\
\hline Huyện Kiến Xương & 22,7 & 16,6 & 18,16 & 19,3 & 12,4 & 13,05 & 14,5 \\
\hline Huyện Vũ Thư & 16,0 & 0,8 & 1,7 & 2,4 & 0 & 0 & 0,2 \\
\hline
\end{tabular}


Bảng 3 đưa ra kết quả tính toán mức độ nguy cơ ảnh hưởng của xâm nhập mặn đến diện tích lúa theo kịch bản RCP 4.5. Từ bảng 3 có thể nhận thấy:

- Ranh giới mặn 1\%o: Trong giai đoạn từ hiện trạng đến năm 2030, diện tích lúa bị nhiễm mặn tại một số huyện là khá cao đặc biệt là các huyện ven biển Thái Thụy và Tiền Hải. Địa phương có nguy cơ nhiễm mặn lớn nhất là huyện Thái Thụy với diện tích ảnh hưởng là 21,2 nghìn ha chiếm $87 \%$ diện tích canh tác lúa của địa phương. Huyện Tiền Hải là 13,4 nghìn ha chiếm $65 \%$. Huyện Kiến Xương là 16,6 chiếm 73,12\%. Thấp nhất là huyện Hưng Hà và thành phố Thái Bình do vị trí nằm sâu trong đất liền và chưa bị ảnh hưởng bởi xâm nhập mặn. Đến giai đoạn năm 2050, cũng với ranh giới mặn 1\%o nhưng diện tích lúa có nguy cơ bị ảnh hưởng tại các địa phương tăng lên đáng kể. Huyện có diện tích lúa bị xâm nhập mặn lớn nhất là huyện Thái Thụy với diện tích bị ảnh hưởng là 22,7 nghìn ha tăng lên 1,5 nghìn ha so với giai đoạn 2030. Tiếp theo là huyện Kiến Xương với diện tích bị ảnh hưởng là 18,16 nghìn ha, tăng lên 1,56 nghìn ha. Huyện Tiền Hải có diện tích bị ảnh hưởng là 13,4 nghìn ha. Thành phố Thái Bình và huyện Hưng Hà trong giai đoạn này vẫn chưa bị ảnh hưởng bởi xâm nhập mặn. Giai đoạn từ 2050 -2100, diện tích lúa có nguy cơ ảnh hưởng bởi xâm nhập mặn đã tăng lên rõ rệt. Mức độ tăng lên nhiều nhất tại huyện Đông Hưng, mức tăng 6,9 nghìn ha so với giai đoạn 2030 và 2,32 nghìn ha so với giai đoạn năm 2050. Thành phố Thái Bình trong giai đoạn này cũng đã bắt đầu bị ảnh hưởng bởi xâm nhập mặn với diện tích bị ảnh hưởng là 1,2 nghìn ha. Huyện Hưng Hà vẫn chưa bị ảnh hưởng bởi xâm nhập mặn.

- Ranh giới mặn 4\%o: So với ranh giới mặn 1\%o, ranh giới mặn 4\%o có mức độ xâm nhập và thay đổi nhỏ hơn. Trong giai đoạn từ hiện trạng đến năm 2030, địa phương có diện tích lúa bị nhiễm mặn lớn nhất là huyện Thái Thụy với diện tích nhiễm mặn là 20,8 nghìn ha chiếm 78,4\% diện tích canh tác lúa tại địa phương, huyện Tiền Hải là 20,6 nghìn ha chiếm $100 \%$, huyện Kiến
Xương là 12,4 nghìn ha chiếm 54,6\%. Với ranh giới này, các huyện Đông Hưng, Hưng Hà, Quỳnh Phụ, Vũ Thư, thành phố Thái Bình chưa bị ảnh hưởng. Đến giai đoạn năm 2050, diện tích lúa có nguy cơ bị ảnh hưởng tại các địa phương tăng lên, lớn nhất là huyện Thái Thụy với 21,32 nghìn ha, diện tích tăng lên là 1,02 nghìn ha. Diện tích ảnh hưởng của huyện Tiền Hải là 20,6 nghìn ha, huyện Kiến Xương là 13,02 nghìn ha. Giai đoạn 2050-2100, Thái Thụy vẫn là huyện có diện tích lúa bị ảnh hưởng lớn nhất với diện tích ảnh hưởng là 22,1 nghìn ha, Thái Thụy là 20,6 nghìn ha, Kiến Xương là 14,5 nghìn ha. Ngoài ra một số huyện đã bắt đầu bị ảnh hưởng bởi xâm nhập mặn như: huyện Quỳnh Phụ, diện tích lúa bị ảnh hưởng là 1,85 nghìn ha. Huyện Đông Hưng, diện tích bị ảnh hưởng là 0,35 nghìn ha; Vũ Thư là 0,2 nghìn ha.

\section{Kết luận và kiến nghị}

Dựa trên bộ số liệu quan trắc độ mặn từ 2000 đến 2017, kết quả phân tích và đánh giá hiện trạng đã cho thấy xâm nhập mặn đã xâm nhập sâu vào trong nội đồng của tỉnh Thái Bình từ 20 - 25 km, độ mặn cao nhất đo được tại các trạm vùng cửa sông dao động từ 21 - 27\%o, độ mặn cao nhất đo được tại trạm Ba Lạt (sông Hồng) lên tới $31,8 \%$; trong các năm từ năm 2003 2012 là giai đoạn có độ mặn lớn và xâm nhập sâu vào trong đất liền, trong giai đoạn này độ mặn cao nhất đo được tại điểm đo Dương Liễu trên sông Hồng (cách biển $25 \mathrm{~km}$ ) lên tới 16,8\%o.

Qua quá trình mô phỏng và dự báo xâm nhận mặn dựa trên mô hình MIKE 11, nhóm tác giả đã xây dựng được đường ranh giới xâm nhập mặn 1\%o, 4\%o tại tỉnh Thái Bình. Có thể thấy trong tương lai dưới ảnh hưởng của $\mathrm{B} Đ K H$, tình trạng xâm nhập mặn trên địa bàn các huyện ven biển ngày càng trở nên nghiêm trọng. Trong khoảng giai đoạn từ hiện trạng đến 2030, mực nước biển dâng lên khoảng $17 \mathrm{~cm}$ thì mức độ xâm nhập mặn diễn biến tương đối ổn định và mức tăng là không lớn. Với ranh giới mặn $1 \%$ mức tăng trung bình là $1,09 \mathrm{~km}$ mức tăng lớn nhất là 1,6 km trên sông Trà Lý, mức tăng thấp 


\title{
BÀI BÁO KHOA HỌC
}

nhất là $0,2 \mathrm{~km}$ trên sông Thái Bình. Tuy nhiên, đến giai đoạn 2050 với mực nước biển dâng lên khoảng $28 \mathrm{~cm}$ thì tương quan mức độ tăng xâm nhập mặn giữa các sông đã có sự thay đổi lớn không chỉ về xu hướng mà cả về lượng. Vẫn là ranh giới mặn $1 \%$ nhưng mức tăng lớn nhất là 4 km diễn ra trên sông Thái Bình, mức tăng thấp nhất là $1,7 \mathrm{~km}$ diễn ra trên sông Trà Lý. Trong giai đoạn từ 2050 đến 2099 khi mà nước biển dâng lên thêm $65 \mathrm{~cm}$ thì mức tăng xâm nhập mặn lớn nhất là $8,1 \mathrm{~km}$ tại sông Thái Bình, thấp nhất là 2,4 km tại sông Trà Lý. Sự xâm nhập mặn nghiêm trọng này sẽ ảnh hưởng lớn tới diện tích trồng lúa tỉnh Thái Bình trong tương lai.

\section{Tài liệu tham khảo}

1. Phạm Hoàng Hải (2007), Nghiên cứu đánh giá thưc trạng xâm nhập mặn vào khu vục nội đồng do ảnh hưởng của sự phát triển nuôi trồng thủy hải sản trong đê tỉnh Thái Bình và đề xuất các biện pháp khắc phuc, Viện Địa lý - Viện Hàn lâm Khoa học và công nghệ Việt Nam.

2. Vũ Thế Hải và cs (2011), Nghiên cứu đề xuất các giải pháp thủy lợi kết hợp nông nghiệp để ứng phó với hạn hán và xâm nhập mặn tại các tỉnh ven biển đồng bằng sông Hồng, Viện Tưới tiêu và môi trường

3. Vũ Hoàng Hoa, Lương Hữu Dũng (2009), Nghiên cúu, dụ báo xu thế diễn biến xâm nhập mặn do nước biển dâng cho vùng cửa sông ven biển Bắc Bộ, Tạp chí Khoa học kỹ thuật Thủy lợi và Môi trường, Số 27 (2009).

4. Nguyễn Văn Hoàng (2011), Nghiên cưu, đánh giá tác động của BĐKH tới tỉnh Thái Bình, đề xuất các giải pháp thích ưng, giảm thiểu thiệt hại, Viện Địa chất - Viện Hàn lâm Khoa học và Công nghệ Việt Nam.

5. Cục thống kê tỉnh Thái Bình (2017), Niên giám thống kê tỉnh Thái Bình năm 2017.

6. Anderson, M.B., Woodrow, P.J. (1989/1998), Rising from the ashes. Development, Strategies in times of Disaster. London: Intermediate Technology Publications (1998 edition).

\section{ASSESSING AND PROJECTING THE SITUATION OF SALINE INTRU- SION FOR COASTAL AREAS IN THAI BINH PROVINCE}

\author{
Do Duc Thang ${ }^{1}$, Tran Hong Thai ${ }^{2}$, Vo Van Hoa ${ }^{1}$ \\ ${ }^{1}$ Red River Delta Regional Hydro-Meteorological Center \\ ${ }^{2}$ Viet Nam Meteorological and Hydrological Administration
}

\begin{abstract}
This paper presents the results of assessment of saline intrusion status for coastal areas in Thai Binh province based on the salinity monitoring data from 2000 to 2017. The assessment results show that saline intrusion can penetrate deeply. In the inner field from $20-25 \mathrm{~km}$, the highest salinity measured at river mouths ranges from 21 - $27 \%$, the highest salinity is measured at Ba Lat station (Red river) up to $31.8 \%$; In the years from 2003 -2012, there was a period of high salinity and deep penetration into the mainland. In this period, the highest salinity measured at the measuring point of Duong Lieu on the Red River (25 km from the sea) reached 16.8\%. The process of simulation and prediction of saline intrusion based on the boundary of saline intrusion $1 \%$ and $4 \%$ in Thai Binh province has shown in the future under the influence of climate change, salinity intrusion in the area Table of coastal districts is becoming more serious.
\end{abstract}

Keywords: Saline intrusion, coastal areas, Thai Binh province. 